\title{
EFEKTIVITAS KOMBINASI TERAPI DINGIN DAN MASASE DALAM PENANGANAN CEDERA ANKLE SPRAIN AKUT
}

Oleh:

Wahyu Tri Atmojo dan Rachmah Laksmi Ambardini Jurusan Pendidikan Kesehatan dan Rekreasi FIK UNY

\begin{abstract}
Abstrak
Penelitian ini bertujuan untuk mengetahui sejauh mana tingkat keberhasilan kombinasi terapi dingin dan masase dalam menangani cedera ankle sprain akut pada atlet pencak silat Daerah Istimewa Yogyakarta.

Penelitian ini merupakan penelitian Pre-Experimental Design dengan rancangan One Group Pretest-Posttest Design. Teknik pengambilan data menggunakan tes dan pengukuran berupa tes awal dan tes akhir dengan penentuan diagnosis cedera ankle sprain akut tersebut menggunakan angket catatan medis. Populasi dalam penelitian ini adalah atlet pemusatan latihan Daerah Istimewa Yogyakarta cabang olahraga pencak silat yang mengalami cedera ankle sprain akut. Teknik sampling dalam penelitian ini menggunakan teknik incidental sampling. Perhitungan jumlah sampel dihitung dengan rumus Slovin dan didapat sampel sebanyak 20 atlet. Teknik analisis data menggunakan uji-t berpasangan setelah sebelumnya melalui uji prasyarat, uji normalitas, dan uji homogenitas.

Hasil penelitian menunjukkan bahwa terdapat perbedaan bermakna pada perlakuan kombinasi terapi dingin dan masase dalam menangani cedera ankle sprain akut, dengan indikasi berkurangnya tanda radang cedera meliputi kemerahan, suhu panas, lingkar ankle, nyeri, serta meningkatnya ROM sendi ankle dengan nilai $\mathrm{p}=0.000(\mathrm{p}<0.05)$. Secara praktis, berdasarkan hasil penelitian di atas dapat disimpulkan bahwa kombinasi terapi dingin dan masase efektif dalam menangani cedera ankle sprain akut pada atlet Pencak Silat Daerah Istimewa Yogyakarta.
\end{abstract}

Kata Kunci: cedera ankle sprain akut, masase, dan terapi dingin.

Olahraga pencak silat merupakan olahraga body contact yang rawan akan cedera. Menurut Garisson (2001: 320) kasus cedera dapat terjadi karena faktor eksternal maupun internal. Faktor eksternal adalah faktor yang unsur-unsurnya berasal dari luar diri atlet tersebut, meliputi perlengkapan yang salah, atlet lain, permukaan bermain, dan cuaca, sedangkan faktor internal adalah faktor yang unsur-unsurnya sudah ada dalam diri atlet tersebut. Unsurunsur tersebut meliputi kelemahan jaringan, fleksibilitas, kelebihan beban, kesalahan biomekanika, kurangnya penyesuaian, ukuran tubuh, kemampuan kinerja, dan gaya bermain.

Cedera yang sering terjadi pada cabang olahraga pencak silat adalah cedera pada tungkai dan kaki sesuai dengan gerakan yang ada di dalam pencak silat yang cenderung menggunakan tungkai dan kakinya. Penggunaan tungkai dan kaki yang dilakukan secara berulang mengakibatkan kaki sering mengalami cedera. Hal ini sejalan dengan hasil 
penelitian Jeffry (2012: 66), yang menemukan bahwa persentase cedera yang paling sering terjadi pada atlet pencak silat Daerah Istimewa Yogyakarta (DIY) adalah cedera tungkai dan kaki yaitu sebesar 25,94 \%. Laoruengthana (2009: 206) menyatakan bahwa pencak silat menjadi cabang olahraga yang atletnya paling sering mengalami cedera dengan 24.4 kasus cedera per 100 atlet. Lebih dari separuh cedera tersebut terjadi pada anggota tubuh bagian bawah. Lutut dan ankle merupakan anggota tubuh bagian bawah yang paling sering mengalami cedera. Hal tersebut menunjukkan bahwa cedera pada tungkai dan kaki dalam olahraga pencak silat memiliki persentase yang tinggi, salah satunya yaitu cedera ankle.

Ankle sprain akut biasa terjadi karena gerakan yang berlebihan (overstretching dan hypermobility) atau trauma yang terjadi secara tiba-tiba, sehingga menyebabkan struktur ligamen teregang melampaui kemampuan normal dan terjadi robekan, baik sebagian maupun total. Sementara ankle sprain kronis merupakan cedera yang terjadi akibat proses akumulasi dari cedera ankle yang berulang-ulang dalam jangka waktu yang relatif lama. Kasus cedera ankle sprain yang dialami atlet pencak silat DIY sering berulang dikarenakan penanganan yang kurang komprehensif. Masalah lain yang ada yaitu perawatan yang dilakukan oleh atlet untuk mempercepat proses penyembuhan masih belum maksimal. Banyak atlet yang mengalami ankle sprain akut masih kurang paham dengan prosedur penanganan dan penyembuhan cedera akut sehingga mengakibatkan proses penyembuhan menjadi lebih lama serta berisiko untuk terjadi cedera ulang.

Selama ini belum ada penanganan khusus cedera ankle sprain akut pada atlet pencak silat DIY. Penanganan hanya terbatas pemberian modalitas terapi dingin di awal terjadinya cedera, sehingga pengendalian proses peradangan (inflamasi) belum maksimal. Selain itu, pada saat ankle sprain terjadi sering dibarengi dengan pergeseran sendi (subluksasi). Ketika sendi ankle mengalami trauma akan mengakibatkan ligamen kompleks lateral teregang melampaui kemampuan normal dan menyebabkan sendi mengalami pergeseran walaupun hanya sebagian. Pergeseran sendi pada kasus cedera ankle sprain akan berdampak pada tumbuhnya jaringan parut yang berlebihan (fibrosis) yang akan membatasi ROM sehingga menyebabkan cedera tersebut berisiko kambuh kembali. Pemulihan kondisi atlet pascacedera yang tidak optimal menyebabkan penurunan prestasi olahraga secara individual maupun tim. Cedera ankle sprain berdampak pada gangguan fungsi dan performance anggota gerak bawah secara khusus. Permasalah pada ankle akan menyebabkan gangguan pola jalan, keterbatasan melakukan aktivitas sehari-hari maupun aktivitas olahraga. Cedera olahraga yang terjadi pada atlet selain mengganggu kesehatan juga dapat mengurangi kesempatan atlet tersebut untuk berprestasi secara maksimal. 
Berdasarkan hasil observasi awal di lapangan, diketahui bahwa banyak atlet pencak silat DIY yang mengalami cedera ankle sprain akut. Penanganan awal yang dilakukan masih terbatas dengan kompres dingin. Penggunaan kombinasi terapi dingin dan masase untuk penanganan awal cedera ankle sprain akut belum banyak dilakukan. Sampai saat ini belum diketahui seberapa jauh efektivitas kombinasi terapi dingin dan masase dalam penanganan cedera ankle sprain akut. Oleh karena itu penelitian terkait dengan hal tersebut di atas perlu dilakukan. Berdasarkan uraian di atas, peneliti ingin meneliti lebih dalam tentang "Efektivitas Kombinasi Terapi Dingin dan Masase dalam Penanganan Cedera Ankle Sprain Akut pada Atlet Pencak Silat DIY”.

\section{KAJIAN PUSTAKA}

\section{Ankle Sprain}

Ankle sprain merupakan cedera yang terjadi karena penguluruan berlebihan (overstretching dan hypermobility) atau trauma pada ligamen kompleks lateral, oleh adanya gaya inversi dan plantar fleksi yang tiba-tiba ketika sedang berolahraga, aktivitas fisik, saat kaki tidak menumpu sempurna pada lantai atau tanah sehinga menyebabkan struktur ligamen teregang melampaui panjang fisiologis dan fungsional normal. Penguluran meyebabkan kerobekan pada ligamen-ligamen kompleks lateral, hal tersebut akan mengakibatkan nyeri pada saat berkontraksi. Nyeri tersebut menyebabkan immobilisasi sehingga terjadi penurunan kekuatan otot dan keterbatasan gerak (Calatayud, 2014: 89). Ankle adalah sendi yang paling utama bagi tubuh guna menjaga keseimbangan tubuh saat melakukan aktivitas, hal tersebut membuat ankle menjadi salah satu lokasi tubuh yang sering mengalami cedera. Umumnya cedera ankle terjadi pada saat kaki melakukan belokan atau memutar sehingga membuat pergelangan kaki meregang pada titik yang akan merobek ligamen atau retak tulang persendiaan pergelangan kaki (Taylor, 2002: 115).

Cedera ankle dapat terjadi karena terkilir secara mendadak dilanjutkan adanya respons dari tubuh dengan ditandai peradangan yang terdiri atas rubor (merah), kalor (panas), tumor (bengkak), dolor (nyeri), dan functiolaesa (penurunan fungsi). Pembuluh darah dilokasi cedera atau bagian ankle akan melebar yaitu terjadi vasodilatasi dengan maksud untuk mengirim lebih banyak nutrisi dan oksigen dalam mendukung penyembuhan. Pelebaran pembuluh darah itulah yang mengakibatkan bagian ankle yang cedera terlihat memerah (rubor). Cairan darah yang banyak dikirim ke lokasi cedera akan merembes keluar dari kapiler menuju ruang antar sel dan menyebabkan bengkak (tumor). 
Dukungan banyak nutrisi dan oksigen, metabolisme di lokasi cedera akan meningkat dengan sisa metabolisme yang berupa panas. Kondisi itulah yang menyebabkan lokasi daerah ankle yang mengalami cedera akan lebih panas (kalor) dibandingkan dengan lokasi lain yang tidak mengalami cedera. Tumpukan sisa metabolisme dan zat kimia lain akan merangsang ujung saraf dibagian ankle yang mengalami cedera dan akan menimbulkan nyeri (dolor). Rasa nyeri tersebut juga dipicu oleh tertekannya ujung saraf karena pembengkakan yang terjadi di lokasi cedera. Tanda peradangan tersebut akan menurunkan fungsi organ atau sendi di lokasi cedera yang dikenal dengan istilah penurunan sendi atau functiolaesa (Wara Kushartanti, 2007: 1).

\section{Terapi Dingin pada Cedera Ankle Sprain Akut}

Terapi dingin disebut juga sebagai cold therapy, merupakan tindakan yang diberikan ke tubuh untuk mengurangi panas, menurunkan temperatur pada area yang dilakukan terapi (Malanga, 2015: 2). Pendapat lain mengenai terapi dingin disampaikan juga oleh Anderson (2009: 166), yang mengatakan bahwa terapi dingin adalah penggunaan dingin pada jaringan lunak tubuh seperti pada jaringan subkutan, otot ataupun sendi untuk mengurangi nyeri dan mengontrol pembengkakan.

Terapi dingin merupakan bagian dari penatalaksanaan cedera yang terutama dilakukan pada fase akut. Efek fisiologis terapi dingin berupa vasokonstriksi arteriola dan venula, penurunan kepekaan akhiran saraf bebas dan penurunan tingkat metabolisme sel sehingga mengakibatkan penurunan kebutuhan oksigen sel. Secara klinis keseluruhan proses tadi dapat mengurangi proses pembengkakan, mengurangi nyeri, mengurangi spasme otot dan resiko kematian sel (Novita, 2009: 2). Adapun tujuan terapi dingin yaitu menurunkan suhu tubuh, mencegah peradangan meluas, mengurangi kongesti, mengurangi perdarahan setempat, dan mengurangi rasa sakit (Asmadi: 2008: 159).

Berdasarkan uraian pendapat ahli di atas dapat disimpulkan bahwa terapi dingin merupakan suatu tindakan yang diberikan kepada anggota tubuh tertentu yang mengalami cedera dengan tujuan menurunkan suhu tubuh, mencegah peradangan meluas, dan mengurangi rasa sakit. Terapi dingin merupakan penatalaksanaan yang utamanya diberikan kepada anggota tubuh yang memiliki cedera pada fase akut. Terapi dingin yang sering digunakan untuk penanganan cedera olahraga adalah ice massage, water imersion, ice packs, dan vacpocoolant sprays (Novita, 2010: 26). Berikut merupakan penjelasan dari teknik di atas: 


\section{A. Ice Massage}

Menurut Eva (2012: 186), ice massage adalah tindakan pemijatan dengan menggunakan es pada area yang sakit. Tindakan ini merupakan hal sederhana yang dapat dilakukan untuk menghilangkan nyeri. Pemberian terapi dingin dilakukan selama 5 sampai 10 menit. Aplikasi menggunakan ice massage dapat memberikan perubahan pada kulit, jaringan subkutan intramuscular, dan suhu pada persendian. Penurunan suhu pada jaringan lunak dapat menstimulasi receptor untuk mengeluarkan simpatetic adrenergic fibers karena terjadinya vasokonstriksi pembuluh darah lokal pada arteri dan vena. Pemberian ice massage dapat mencegah terjadinya kerusakan otot yang lebih berat karena rusaknya pembuluh darah di sekitar otot. Pemberian ice massage akan memperlambat metabolisme pembuluh darah lokal pada area cedera sebagai akibat dari reaksi hipoksia, sehingga terjadinya inflamasi dan pemicu reaksi munculnya nyeri dapat diminimalisasi (Rakasiwi, 2014: 28)

\section{B. Water Immersion}

Water immersion merupakan terapi mandi di dalam air dingin dalam jangka waktu maksimal 20 menit. Terapi ini dapat digunakan untuk mengurangi bengkak dan memulihkan cedera pascalatihan. Pendapat tersebut diperkuat oleh Anderson (2009: 169), bahwa water immersion adalah metode yang digunakan untuk mengurangi suhu pada permukaan tubuh bagian distal, seperti lengan, tangan, kaki atau ankle. Water immersion memiliki efek analgesik, metode ini sering digunakan pada fase inflamasi untuk mengurangi bengkak setelah terjadi trauma. Terapi ini sering dilakukan untuk pemulihan pascalatihan maupun kompetisi. Penderita berendam di dalam air yang sudah didinginkan yaitu dengan cara mencampur air dan es untuk mendapatkan suhu $10^{\circ}$ sampai dengan $15^{\circ} \mathrm{C}$. Proses ini berlangsung sekitar 10 sampai dengan 15 menit. Ketika nyeri berkurang, terapi dihentikan dan dilanjutkan terapi lain seperti massage atau stretching (Novita, 2010: 28).

C. Ice Pack

Ice pack merupakan sebuah kompres es yang dikemas dengan menggunakan sarung tangan karet yang diisi batu es dan dibungkus dengan sesuatu yang bersih seperti kain lap sekali pakai atau handuk sekali pakai (Wenniarti, 2016: 378). Pendapat lain yaitu disampaikan oleh Novita (2010: 28), bahwa pada prinsipnya ice packs merupakan kemasan yang dapat menyimpan es dan membuat es dapat terjaga dalam waktu relatif lama di luar freezer daripada kemasan plastik. Ice packs dapat digunakan selama 15 sampai 20 menit. Pada kemasan ice packs, diperlukan handuk untuk mengeringkan air kondensasi. Dari beberapa metode terapi dingin yang ada, terapi ini sering digunakan 
untuk mengurangi bengkak pada ankle. Selain perlatan yang mudah didapatkan, penggunaan metode terapi ini lebih praktis dari metode yang lain.

D. Vapocoolant Spray

Vapocoolant spray merupakan semprotan yang biasanya berisi fluoromethane atau ethyl chloride. Vacoopolant spray sering digunakan untuk mengurangi nyeri akibat spasme otot serta meningkatkan range of motion (Novita, 2010: 27). Prosedur pemakaian yakni dengan menyemprotkan vapocoolant membentuk sudut $30^{\circ}$ dengan kulit pada jarak 30 sampai $50 \mathrm{~cm}$ dari kulit, penyemprotan dilakukan dari arah proksimal ke distal otot dengan kecepatan penyemprotan sekitar $10 \mathrm{~cm}$ per detik dan dapat diulang sampai dengan 2-3 kali. Hal yang perlu diperhatikan adalah penggunaan vapocoolant harus dilakukan sesuai prosedur untuk menghindari frozen bite.

Terapi dingin merupakan modalitas terapi yang dapat menyerap suhu jaringan sehingga terjadi penurunan suhu jaringan melalui mekanisme konduksi. Efek pendinginan yang terjadi bergantung pada jenis aplikasi terapi dingin, lama terapi, dan konduktivitas. Inti dari terapi dingin adalah menyerap kalori area lokal cedera sehingga terjadi penuruan suhu (Novita, 2010: 22).

Tabel 1. Efek Fisiologis Terapi Dingin pada Tubuh

\begin{tabular}{|c|l|l|}
\hline No & \multicolumn{1}{|c|}{ Variabel } & \multicolumn{1}{c|}{ Efek } \\
\hline 1 & Spasme Otot & Menurun \\
\hline 2 & Persepsi Nyeri & Menurun \\
\hline 3 & Aliran darah & Menurun sampai 10 menit pertama \\
\hline 4 & Kecepatan metabolisme & Menurun \\
\hline 5 & Elastisitas kolagen & Menurun \\
\hline 6 & Kekakuan sendi & Meningkat \\
\hline 7 & Permeabilitas kapiler & Meningkat \\
\hline 8 & Pembengkakan & $\begin{array}{l}\text { Dapat mengurangi pembengkakan lanjut tapi } \\
\text { relatif tidak menghentikan pembengkakan yang } \\
\text { sudah terjadi }\end{array}$ \\
\hline
\end{tabular}

Sumber: Novita (2010: 24)

Terapi dingin dapat mengurangi suhu daerah yang sakit, membatasi aliran darah, dan mencegah cairan masuk ke jaringan di sekitar luka. Hal ini akan mengurangi nyeri dan pembengkakan. Terapi dingin dapat mengurangi sensitivitas dari akhiran saraf yang berakibat terjadinya peningkatan ambang batas rasa nyeri. Terapi dingin juga akan mengurangi kerusakan jaringan dengan jalan mengurangi metabolisme lokal sehingga kebutuhan oksigen jaringan menurun. Respons neuro-hormonal terhadap terapi dingin adalah sebagai berikut: (a) pelepasan endorfhin, (b) penurunan transmisi saraf sensoris, 
(c) penurunan aktivitas badan sel saraf, (d) penurunan iritan yang merupakan limbah metabolisme sel,dan (e) peningkatan ambang nyeri.

Tabel. 2 Respons Kulit Pada Aplikasi Dingin

\begin{tabular}{|c|c|c|}
\hline Tahap & Waktu Pemberian Aplikasi & Respon \\
\hline 1 & $0-3$ menit & Sensasi dingin \\
\hline 2 & $2-7$ menit & Rasa terbakar, nyeri \\
\hline 3 & $5-12$ menit & Anestesi relatif kulit \\
\hline
\end{tabular}

Sumber: Novita (2010: 24)

Novita (2010: 23-24) mengungkapkan secara fisiologis pada 15 menit pertama setelah pemberian aplikasi dingin (suhu $10^{\circ} \mathrm{C}$ ) terjadi vasokonstriksi arteriola dan venula secara lokal. Vasokonstriksi ini disebabkan oleh aksi refleks dari otot polos yang timbul akibat stimulasi sistem saraf otonom dan pelepasan epinephrin dan norepinephrin. Walaupun demikian apabila dingin tersebut terus diberikan selama 15 sampai dengan 30 menit akan timbul fase vasodilatasi yang terjadi intermiten selama 4 sampai 6 menit. Periode ini dikenal sebagai respons hunting. Respons hunting terjadi untuk mencegah terjadinya kerusakan jaringan akibat jaringan mengalami anoxia jaringan. Selain menimbulkan vasokonstriksi, sensasi dingin juga menurunkan eksitabilitas akhiran saraf bebas sehingga menurunkan kepekaan terhadap rangsang nyeri. Aplikasi dingin juga dapat mengurangi tingkat metabolisme sel sehingga limbah metabolisme menjadi berkurang. Penurunan limbah metabolisme pada akhirnya dapat menurunkan spasme otot.

\section{Peran Terapi Dingin dan Masase pada Ankle Sprain Akut}

Tujuan terapi dingin yaitu menurunkan suhu tubuh, mencegah peradangan meluas, mengurangi kongesti, mengurangi perdarahan setempat, dan mengurangi rasa sakit. Secara fisiologis setelah pemberian aplikasi dingin (suhu $10^{\circ} \mathrm{C}$ ) pada 15 menit pertama akan terjadi vasokonstriksi arteriola dan venula, penurunan kepekaan akhiran saraf bebas dan penurunan tingkat metabolisme sel sehingga mengakibatkan penurunan kebutuhan oksigen sel. Secara klinis keseluruhan proses tadi dapat mengurangi proses pembengkakan, mengurangi nyeri, mengurangi spasme otot, dan risiko kematian sel.

Terapi dingin akan menurunkan suhu daerah yang sakit, membatasi aliran darah dan mencegah cairan masuk ke jaringan di sekitar luka. Hal ini akan berefek pada berkurangnya intensitas kemerahan, panas, nyeri dan pembengkakan. Selain itu, terapi dingin juga dapat mengurangi prostaglandin yang memperkuat reseptor nyeri, menghambat proses inflamasi, merangsang pelepasan endorfin sehingga menurunkan transmisi nyeri (Wenniarti, 2016: 
378). Selain terapi dingin, masase juga memiliki peran terhadap penurunan nyeri dan peningkatan ruang gerak sendi.

Pengaruh masase pada saraf bisa menenangkan dan bersifat sedatif, memberikan rasa ringan pada saraf yang terganggu yang disebabkan oleh ketidaknyamanan seperti tegang, lelah, dan sakit. Selain itu, pengaruh masase juga bersifat menstimulasi, meningkatkan aktivitas otot, pembuluh darah, dan kelenjar. Masase dalam hal ini merupakan manipulasi dari struktur jaringan lunak yang dapat menenangkan serta mengurangi stres psikologis dengan meningkatkan hormon morphin endogen seperti endorfin, enkefalin dan dinorfin sekaligus menurunkan kadar stres hormon seperti hormon cortisol, norepinephrine, dan dopamine (Best et al. 2008: 446). Secara fisiologis, masase terbukti dapat menurunkan denyut jantung, meningkatkan sirkulasi darah dan limfe, mengurangi ketegangan otot, meningkatkan jangkauan gerak sendi serta mengurangi nyeri.

Terapi dingin memiliki peran yang tinggi sama halnya dengan masase yaitu memicu hormon endorfin keluar dan mengurangi rasa nyeri, sehingga jika rasa nyeri berkurang, secara tidak sadar ruang gerak sendi juga akan bertambah. Kombinasi konsep kedua cara terapi yaitu terapi dingin dan masase lebih baik digunakan karena kedua perlakuan tersebut merangsang pemulihan cedera ankle sprain akut. Secara keseluruhan pengaruh dari kedua terapi tersebut dapat menyebabkan berkurangnya indikasi tanda peradangan (merah, panas, bengkak, nyeri, dan penurunan fungsi) pada cedera ankle sprain akut.

\section{METODE PENELITIAN}

Desain penelitian yang digunakan dalam penelitian ini adalah Pre-Experimental Design dengan rancangan One Group Pretest-Posttest Design, yaitu desain penelitian yang terdapat pretest sebelum diberi perlakuan dan posttest setelah diberi perlakuan tanpa menggunakan variabel kontrol. Populasi dalam penelitian ini adalah atlet pemusatan latihan Daerah Istimewa Yogyakarta cabang olahraga pencak silat yang pernah mengikuti berbagai turnamen tingkat daerah, regional, maupun nasional. Sampel diambil selama periode bulan Maret sampai Mei 2017. Teknik yang digunakan yaitu incidental sampling, bahwa siapa saja yang secara kebetulan bertemu dengan peneliti dapat digunakan sebagai sampel, bila dipandang orang itu memenuhi syarat dan bersedia sebagai sumber data. Instrumen yang digunakan dalam penelitian ini adalah skala nyeri untuk mengukur tingkat perasaan nyeri dan goniometer untuk mengukur derajat sudut pergerakan sendi ankle. 
Tabel 3. Derajat ROM

\begin{tabular}{|c|c|c|}
\hline \multicolumn{3}{|c|}{ Derajat Tingkat Gerak } \\
\hline No & Action & Normal \\
\hline 1 & Plantar fleksi & $40^{\circ}$ \\
\hline 2 & Dorsofleksi & $20^{\circ}$ \\
\hline 3 & Inversi & $20^{\circ}$ \\
\hline 4 & Eversi & $10^{\circ}$ \\
\hline
\end{tabular}

(Sumber: Anderson, 2009: 688)

\section{Skala 1. Nyeri}

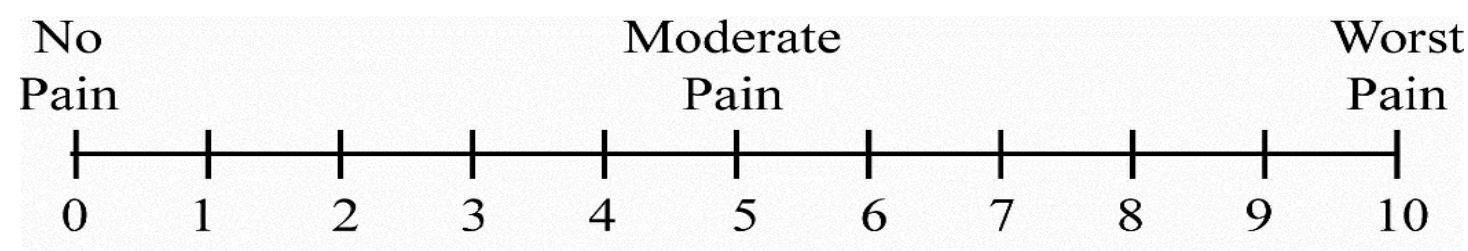

Gambar 1. Visual Analog Scale

(Sumber: http://assessment-module.yale.edu/im-palliative/visual-analogue-scale diunduh pada tanggal 7 Maret 2017 pukul 11:50 WIB)

Tabel 4. Perasaan Nyeri

\begin{tabular}{|c|c|}
\hline Nyeri & Skala \\
\hline 0 & Tidak nyeri \\
\hline $1-3$ & Nyeri ringan \\
\hline $4-7$ & Nyeri sedang \\
\hline $8-10$ & Nyeri berat \\
\hline
\end{tabular}

Tabel 5. Pemeriksaan Fisioterapi untuk Diagnosis Ankle Sprain Akut

\begin{tabular}{|c|l|l|l|}
\hline No & Assessment & \multicolumn{1}{|c|}{ Fokus Assessment } & \multicolumn{1}{|c|}{ Hasil } \\
\hline 1 & Anamnesis & $\begin{array}{l}\text { Nama, Umur, Kategori, } \\
\text { Keluhan Utama, Riwayat } \\
\text { Penyakit. }\end{array}$ & $\begin{array}{l}\text { a. Rasa nyeri pada ankle } \\
\text { bagian lateral } \\
\text { b. Teradapat riwayat trauma } \\
\text { pada ankle. }\end{array}$ \\
3 & Inspeksi & Tanda-tanda inflamasi & $\begin{array}{l}\text { Tampak adanya kemerahan, } \\
\text { panas, dan edema }\end{array}$ \\
4 & Fungsi & ROM & $\begin{array}{l}\text { Penurunan ruang gerak } \\
\text { plantarfleksi, dorsofleksi, } \\
\text { inversi dan eversi. }\end{array}$ \\
Kegiatan sehari-hari & $\begin{array}{l}\text { Mengalami keterbatasan } \\
\text { dalam berjalan, jongkok, } \\
\text { jinjit, dan berdiri satu kaki. }\end{array}$ \\
\hline
\end{tabular}

Pasien diberikan perlakukan terapi dingin dan masase dengan prosedur sebagai berikut: 
a. Terapis memberikan penjelasan kepada pasien apa yang akan dilakukan serta memberitahukan tujuan menggunakan ice pack dan masase frirage.

b. Sebelum pasien diberikan perlakuan dingin dengan ice pack dan masase frirage, pasien terlebih dahulu diukur perasaan nyeri menggunakan skala nyeri dan derajat ROM menggunakan goniometer.

c. Langkah selanjutnya pasien diminta untuk berbaring di lantai dengan posisi kaki yang mengalami cedera diluruskan.

d. Kemudian ice pack $\left(10-15^{\circ} \mathrm{C}\right)$ ditempelkan pada ankle yang mengalami cedera dan didiamkan selama 10-15 menit dengan posisi kaki lebih tinggi dari jantung, pengambilan waktu dilakukan oleh terapis menggunakan stopwatch.

e. Apabila sebelum 15 menit pasien merasakan kebas dan kesemutan, ice pack segera dilepas.

f. Setelah dilakukan terapi dingin menggunakan ice pack dilanjut dengan melakukan masase frirage dengan prosedur sebagai berikut:

Tabel 6. Treatment Manipulasi Masase Frirage untuk Cedera Ankle

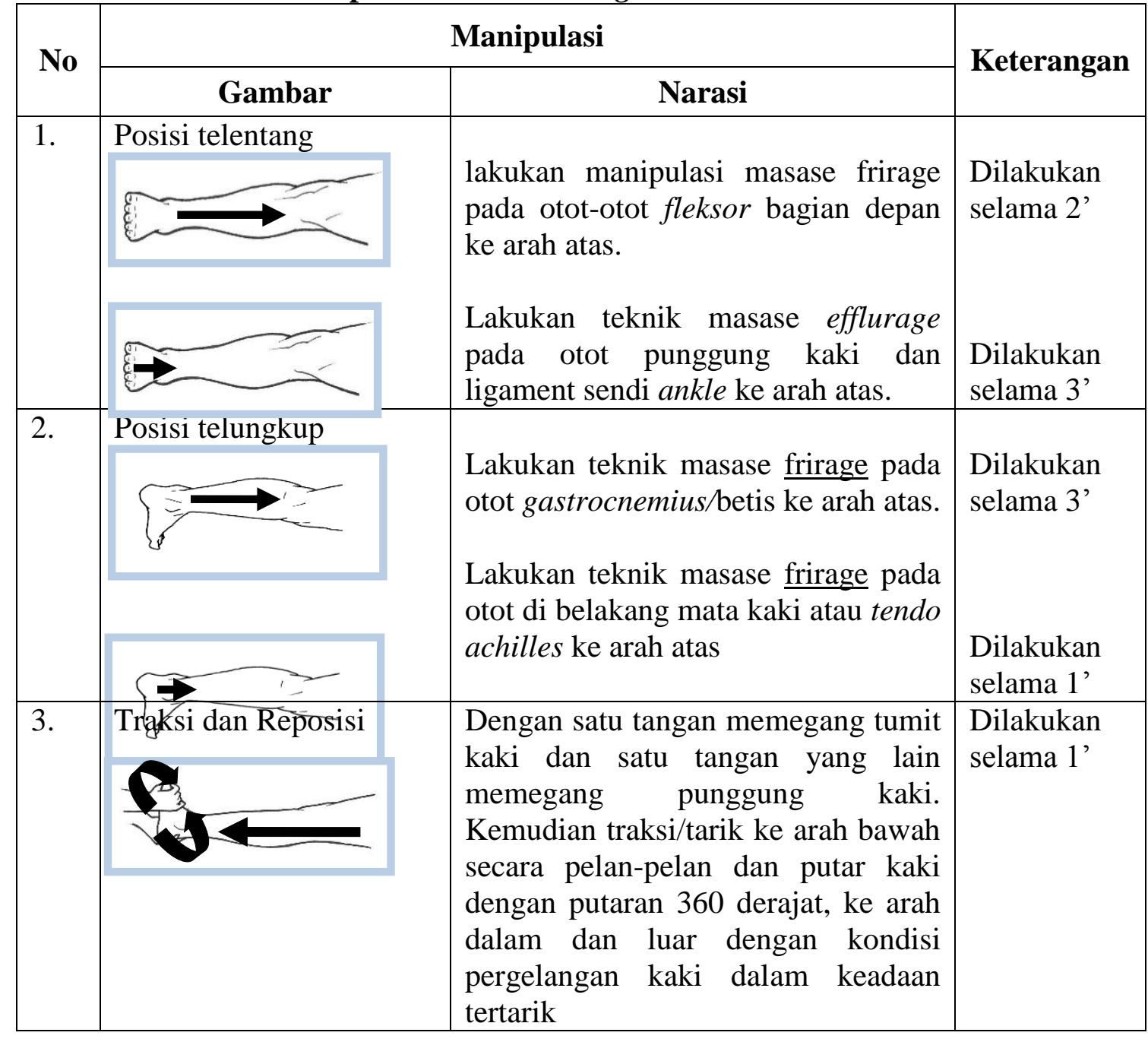




\section{Teknik Pengumpulan Data}

Data yang dikumpulkan dalam penelitian ini adalah data yang diperoleh dengan menggunakan tes dan pengukuran dari atlet pencak silat puslatda DIY yang mengalami cedera ankle sprain akut. Cara pelaksanaan pengumpulan data ini menggunakan dua tahap, tahap awal dan tahap akhir yaitu sebelum diberi perlakuan terapi dingin dan masase serta sesudah diberi perlakuan terapi dingin dan masase. Tahap awal dalam pengumpulan data ini yaitu, responden terlebih dahulu mengisi angket catatan medis sebelum diberikan perlakuan terapi dingin dan masase. Setelah diberikan perlakuan terapi dingin dan masase responden akan diukur kembali perasaan nyeri dan ROM dengan mengisi angket catatan medis kembali. Perbandingan hasil pengisian kedua angket (pretest-posttest) tersebut akan menunjukkan tingkat keberhasilan kombinasi terapi dingin dan masase. Adapun pedoman pelaksanaan terapi dingin dan masase sebagai berikut:

Tabel 7. Pedoman Pelaksanaan Kombinasi Terapi Dingin dan Masase

\begin{tabular}{|c|c|c|c|c|c|}
\hline No & Tipe & Bentuk & Frekuensi & Waktu & Intensitas \\
\hline 1 & $\begin{array}{l}\text { Terapi } \\
\text { dingin }\end{array}$ & Ice Pack & $\begin{array}{l}\text { Satu kali } \\
\text { pertemuan }\end{array}$ & $\begin{array}{l}10-15 \\
\text { menit }\end{array}$ & $\begin{array}{lr}\text { Kompres } & \text { dengan } \\
\text { air dingin } & \text { dengan } \\
\text { suhu } & 10-15 \\
\text { derajat celcius. }\end{array}$ \\
\hline \multirow[t]{4}{*}{2} & \multirow[t]{4}{*}{ Masase } & $\begin{array}{l}\text { Efflurage dan friction } \\
\text { tungkai bawah bagian } \\
\text { depan }\end{array}$ & \multirow[t]{4}{*}{$\begin{array}{l}\text { Satu kali } \\
\text { pertemuan }\end{array}$} & 3 menit & \multirow[t]{3}{*}{$\begin{array}{l}\text { Menyesuaikan } \\
\text { besar/tebal oto } \\
\text { dan nyeri otot }\end{array}$} \\
\hline & & $\begin{array}{l}\text { Efflurage punggung } \\
\text { kaki }\end{array}$ & & 2 menit & \\
\hline & & $\begin{array}{l}\text { Efflurage dan friction } \\
\text { tungkai bawah bagian } \\
\text { belakang }\end{array}$ & & 3 menit & \\
\hline & & Traksi dan Reposisi & & 1 menit & \\
\hline
\end{tabular}

\section{HASIL PENELITIAN}

Pada penelitian ini efektivitas kombinasi terapi dingin dan masase diamati pada penurunan intensitas kemerahan (rubor), suhu (kalor), lingkar ankle (tumor), perasaan nyeri (dolor) meliputi nyeri tekan, berjalan, jongkok, jinjit, dan berdiri satu kaki serta peningkatan kemampuan ROM meliputi plantarfleksi, dorsofleksi, inversi, dan eversi. Data penelitian ini diperoleh dari pretest dan posttest pada responden, diamati sebanyak dua kali yaitu sebelum dan sesudah diberikan perlakuan kombinasi terapi dingin dan masase. Hasil analisis deskriptif pada data penelitian adalah sebagai berikut:

A. Kemerahan pada Lokasi Cedera (Rubor) 
Tabel 8. Distribusi Frekuensi Intensitas Kemerahan (Rubor)

\begin{tabular}{|c|c|c|c|c|c|}
\hline \multirow{2}{*}{ No } & Intensitas & \multicolumn{2}{|c|}{ Pretest } & \multicolumn{2}{c|}{ Posttest } \\
\cline { 3 - 6 } & Kemerahan & Jumlah & $(\%)$ & Jumlah & $(\%)$ \\
\hline 1 & Negatif & 4 & 20 & 18 & 90 \\
\hline 2 & Positif 1 & 12 & 60 & 2 & 10 \\
\hline 3 & Positif 2 & 4 & 20 & 0 & 0 \\
\hline 4 & Positif 3 & 0 & 0 & 0 & 0 \\
\hline \multicolumn{2}{|c|}{ Total } & 20 & $100 \%$ & 20 & $100 \%$ \\
\hline
\end{tabular}

Hasil pretest intensitas kemerahan lokasi cedera didapat mean sebesar 1,00, sedangkan posttest kemerahan lokasi cedera didapat mean sebesar 0,10. Berikut merupakan tabel distribusi efektivitas intensitas kemerahan lokasi cedera.

Tabel 9. Distribusi Efektivitas Intensitas Kemerahan Lokasi Cedera

\begin{tabular}{|c|c|c|c|}
\hline Pretest & Posttest & $\Delta$ & Efektivitas \\
\hline 1,00 & 0,10 & $-0,90$ & $90,00 \%$ \\
\hline
\end{tabular}

Dari hasil di atas dapat disimpulkan bahwa kombinasi terapi dingin dan masase dapat menurunkan intensitas kemerahan pada lokasi cedera dengan efektivitas sebesar $90 \%$. Pengaruh dingin pada daerah cedera dapat mengurangi suhu daerah yang sakit, membatasi aliran darah dan mencegah cairan masuk ke jaringan di sekitar luka (Novita, 2010: 23). Pengaruh masase pada cedera yaitu dapat meningkatkan aktivitas pompa vena dan limfe (getah bening) secara artifisial untuk mempercepat pemulihan melalui percepatan sirkulasi dengan mengangkut kembali cairan tubuh yang berada di luar pembuluh darah (Giriwijoyo, 2012: 274). Secara fisiologis kedua terapi tersebut dapat mengurangi proses peradangan yang terjadi berupa kemerahan, panas, dan bengkak.

B. Suhu pada Lokasi Cedera

Adapun tabel distribusi frekuensi pretest dan posttest intensitas suhu (kalor) disajikan sebagai berikut:

Tabel 10. Distribusi Frekuensi Intensitas Suhu (Kalor)

\begin{tabular}{|c|c|c|c|c|c|}
\hline \multirow{2}{*}{ No } & Intensitas & \multicolumn{2}{|c|}{ Pretest } & \multicolumn{2}{c|}{ Posttest } \\
\cline { 3 - 6 } & Kemerahan & Jumlah & $(\%)$ & Jumlah & $(\%)$ \\
\hline 1 & Negatif & 0 & 00 & 16 & 80 \\
\hline 2 & Positif 1 & 16 & 80 & 4 & 20 \\
\hline 3 & Positif 2 & 4 & 20 & 0 & 0 \\
\hline 4 & Positif 3 & 0 & 0 & 0 & 0 \\
\hline \multicolumn{2}{|c|}{ Total } & 20 & $100 \%$ & & 20 \\
\hline
\end{tabular}


Berikut merupakan tabel distribusi frekuensi efektivitas data intensitas suhu panas lokasi cedera:

Tabel 11. Distribusi Efektivitas Intensitas Suhu (Kalor)

\begin{tabular}{|c|c|c|c|}
\hline Pretest & Posttest & $\Delta$ & Efektivitas \\
\hline 1,20 & 0,20 & $-1,00$ & $83,33 \%$ \\
\hline
\end{tabular}

Dari hasil di atas dapat disimpulkan bahwa perlakuan kombinasi terapi dingin dan masase dapat menurunkan intensitas suhu pada lokasi cedera sebesar 83,33\%. Pengaruh dingin pada daerah cedera dapat mengurangi suhu daerah yang sakit, membatasi aliran darah dan mencegah cairan masuk ke jaringan di sekitar luka (Novita, 2010: 23). Pengaruh masase pada cedera yaitu dapat meningkatkan aktivitas pompa vena dan limfe (getah bening) secara artifisial untuk mempercepat pemulihan melalui percepatan sirkulasi dengan mengangkut kembali cairan tubuh yang berada di luar pembuluh darah (Giriwijoyo, 2012: 274). Secara fisiologis kedua terapi tersebut dapat mengurangi proses peradangan yang terjadi berupa kemerahan, panas, dan bengkak.

C. Lingkar Ankle

Adapun tabel distribusi frekuensi pretest dan posttest lingkar ankle disajikan sebagai berikut:

Tabel 12. Distribusi Frekuensi Lingkar Ankle

\begin{tabular}{|c|c|c|c|c|c|c|}
\hline \multirow{2}{*}{$\begin{array}{c}\text { Lokasi } \\
\text { Pengukuran }\end{array}$} & \multicolumn{3}{|c|}{ Pretest } & \multicolumn{3}{c|}{ Posttest } \\
\cline { 2 - 7 } & Kisaran & $\begin{array}{c}\text { Rata- } \\
\text { rata }\end{array}$ & SD & Kisaran & $\begin{array}{c}\text { Rata- } \\
\text { rata }\end{array}$ & SD \\
\hline Ankle & $45-54,5$ & 50,95 & 2,43 & $44-53$ & 49,83 & 2,30 \\
\hline
\end{tabular}

Berikut merupakan tabel distribusi efektivitas data lingkar ankle pada lokasi cedera.

Tabel 13. Distribusi Efektivitas Data Lingkar Ankle

\begin{tabular}{|c|c|c|c|}
\hline Pretest & Posttest & $\Delta$ & Efektivitas \\
\hline 50,95 & 49,83 & $-1,12$ & $2,08 \%$ \\
\hline
\end{tabular}

Dari hasil di atas dapat disimpulkan bahwa terapi dingin dan masase dapat menurunkan lingkar ankle pada lokasi cedera sebesar 2,08\%. Pengeruh dingin menyebabkan penyempitan pembuluh darah (vasokonstriksi) sehingga mengurangi permeabilitas aliran darah lokal dan mengurangi tingkat perdarahan yang terjadi pada 
tempat cedera (Bleakley, 2006: 704). Pengaruh masase pada cedera yaitu dapat meningkatkan aktivitas pompa vena dan limfe (getah bening) secara artifisial untuk mempercepat pemulihan melalui percepatan sirkulasi dengan mengangkut kembali cairan tubuh yang berada di luar pembuluh darah (Giriwijoyo, 2012: 274). Secara fisiologis kedua terapi tersebut dapat mengurangi proses peradangan yang terjadi berupa kemerahan, panas dan bengkak.

D. Skala Perasaan Nyeri

1. Nyeri Tekan

Adapun tabel distribusi frekuensi pretest dan posttest skala perasaan nyeri tekan disajikan sebagai berikut:

Tabel 14. Distribusi Frekuensi Data Perasaan Nyeri Tekan

\begin{tabular}{|c|c|c|c|c|}
\hline No & $\begin{array}{c}\text { Waktu } \\
\text { Penilaian }\end{array}$ & Kisaran & Rata-rata & SD \\
\hline 1 & Pretest & $5-8$ & 7,10 & 0,97 \\
\hline 2 & Posttest & $2-4$ & 2,10 & 0,60 \\
\hline
\end{tabular}

Berikut merupakan tabel distribusi efektivitas data perasaan nyeri tekan.

Tabel 15. Distribusi Efektivitas Data Perasaan Nyeri Tekan

\begin{tabular}{|c|c|c|c|}
\hline Pretest & Posttest & $\Delta$ & Efektivitas \\
\hline 7,10 & 2,10 & $-5,00$ & $70,42 \%$ \\
\hline
\end{tabular}

Dari hasil di atas dapat disimpulkan bahwa terapi dingin dan masase dapat menurunkan skala perasaan nyeri tekan sebesar 70,42\%.

2. Nyeri Berjalan

Adapun tabel distribusi frekuensi pretest dan posttest skala perasaan nyeri berjalan disajikan sebagai berikut:

Tabel 16. Distribusi Frekuensi Data Perasaan Nyeri Berjalan

\begin{tabular}{|c|c|c|c|c|}
\hline No & Waktu Penilaian & Kisaran & Rata-rata & SD \\
\hline 1 & Pretest & $4-6$ & 4,60 & 0,60 \\
\hline 2 & Posttest & $1-2$ & 1,10 & 0,31 \\
\hline
\end{tabular}

Berikut merupakan tabel distribusi efektivitas data perasaan nyeri berjalan.

Tabel 17. Distribusi Efektivitas Data Perasaan Nyeri Berjalan

\begin{tabular}{|c|c|c|c|}
\hline Pretest & Posttest & $\Delta$ & Efektivitas \\
\hline 4,60 & 1,10 & $-3,5$ & $76.10 \%$ \\
\hline
\end{tabular}


Dari hasil di atas dapat disimpulkan bahwa terapi dingin dan masase dapat menurunkan skala perasaan nyeri berjalan sebesar $76.10 \%$.

3. Nyeri Jongkok

Adapun tabel distribusi frekuensi pretest dan posttest skala perasaan nyeri jongkok disajikan sebagai berikut:

Tabel 18. Distribusi Frekuensi Data Skala Perasaan Nyeri Jongkok

\begin{tabular}{|c|c|c|c|c|}
\hline No & Waktu Penilaian & Kisaran & Rata-rata & SD \\
\hline 1 & Pretest & $4-7$ & 4,90 & 0,91 \\
\hline 2 & Posttest & $1-2$ & 1,30 & 0,47 \\
\hline
\end{tabular}

Berikut merupakan tabel distribusi efektivitas data perasaan nyeri jongkok.

Tabel 19. Distribusi Efektivitas Data Perasaan Nyeri Jongkok

\begin{tabular}{|c|c|c|c|}
\hline Pretest & Posttest & $\Delta$ & Efektivitas \\
\hline 4,90 & 1,30 & $-3,60$ & $73,47 \%$ \\
\hline
\end{tabular}

Dari hasil di atas dapat disimpulkan bahwa terapi dingin dan masase dapat menurunkan skala perasaan nyeri jongkok sebesar 73,47 \%.

4. Nyeri Jinjit

Adapun tabel distribusi frekuensi pretest dan posttest skala perasaan nyeri jinjit disajikan sebagai berikut:

Tabel.20 Distribusi Frekuensi Data Perasaan Nyeri Jinjit

\begin{tabular}{|c|c|c|c|c|}
\hline No & Waktu Penilaian & Kisaran & Rata-rata & SD \\
\hline 1 & Pretest & $4-7$ & 5,85 & 0,88 \\
\hline 2 & Posttest & $1-3$ & 1,45 & 1,69 \\
\hline
\end{tabular}

Berikut merupakan tabel distribusi efektivitas data perasaan nyeri jinjit.

Tabel.21 Distribusi Efektivitas Data Perasaan Nyeri Jinjit

\begin{tabular}{|c|c|c|c|}
\hline Pretest & Posttest & $\Delta$ & Efektivitas \\
\hline 5,85 & 1,45 & $-4,40$ & $75,20 \%$ \\
\hline
\end{tabular}

Dari hasil di atas dapat disimpulkan bahwa terapi dingin dan masase dapat menurunkan skala perasaan nyeri jinjit sebesar 75,20\%. 
5. Nyeri Berdiri Satu Kaki

Adapun tabel distribusi frekuensi pretest dan posttest skala perasaan nyeri berdiri satu kaki disajikan sebagai berikut:

Tabel 22. Distribusi Frekuensi Data Perasaan Nyeri Berdiri Satu Kaki

\begin{tabular}{|c|c|c|c|c|}
\hline No & Waktu Penilaian & Kisaran & Rata-rata & SD \\
\hline 1 & Pretest & $4-6$ & 5,15 & 0,67 \\
\hline 2 & Posttest & $1-2$ & 1,10 & 0,31 \\
\hline
\end{tabular}

Berikut merupakan tabel distribusi efektivitas data perasaan nyeri berdiri satu kaki.

Tabel 23. Distribusi Efektivitas Data Perasaan Nyeri Berdiri Satu Kaki

\begin{tabular}{|c|c|c|c|}
\hline Pretest & Posttest & $\Delta$ & Efektivitas \\
\hline 5,15 & 1,10 & $-4,45$ & $40,50 \%$ \\
\hline
\end{tabular}

Berdasarkan hasil di atas dapat disimpulkan bahwa terapi dingin dan masase dapat menurunkan skala perasaan nyeri berdiri satu kaki sebesar 40,50 \%.

6. Range of Motion (ROM)

Deskripsi data pretest dan posttest didasarkan pada data yang diperoleh dari hasil tes pengukuran pada saat sebelum dan sesudah. Berikut tabel kenaikan atau efektivitas kombinasi terapi dingin dan masase dalam meningkatkan ROM pada cedera ankle sprain akut:

Tabel 24. Range of Motion Ankle

\begin{tabular}{|c|c|c|c|c|}
\hline \multirow{2}{*}{ Gerakan } & \multicolumn{2}{|c|}{ Pretest } & \multicolumn{2}{c|}{ Posttest } \\
\cline { 2 - 5 } & Rata-rata & SD & Rata-rata & SD \\
\hline Plantarfleksi & 36,95 & 5,41 & 44,05 & 5,12 \\
\hline Dorsofleksi & 12,10 & 4,83 & 18,40 & 4,56 \\
\hline Inversi & 14,60 & 4,24 & 21,10 & 3,32 \\
\hline Eversi & 7,40 & 1,93 & 11,45 & 2,42 \\
\hline
\end{tabular}

Hasil analisis deskriptif data ROM pretest dan posttest adalah sebagai berikut:

a. Gerakan Plantar fleksi

Tabel 25. Distribusi Efektivitas Data Derajat ROM Plantarfleksi

\begin{tabular}{|c|c|c|}
\hline Pretest & Posttest & Efektivitas \% \\
\hline 36,95 & 44,05 & $19,21 \%$ \\
\hline
\end{tabular}


Berdasarkan perhitungan di atas diketahui bahwa persentase keberhasilan kombinasi terapi dingin dan masase dalam menangani cedera ankle sprain akut pada pengukuran gerak plantarfleksi adalah sebesar $19.21 \%$.

b. Gerakan Dorsofleksi

Tabel 26. Distribusi Efektivitas Data Derajat ROM Dorsofleksi

\begin{tabular}{|c|c|c|}
\hline Pretest & Posttest & Efektivitas \% \\
\hline 12,10 & 18,40 & $52.06 \%$ \\
\hline
\end{tabular}

Berdasarkan perhitungan di atas diketahui bahwa persentase keberhasilan kombinasi terapi dingin dan masase dalam menangani cedera ankle sprain akut pada pengukuran gerak dorsofleksi adalah sebesar $52.06 \%$.

c. Gerakan Inversi

\section{Tabel 27. Distribusi Data Rerata untuk Gerakan Dorsofleksi}

\begin{tabular}{|c|c|c|}
\hline Pretest & Posttest & Efektivitas \% \\
\hline 14,60 & 21,10 & $44.52 \%$ \\
\hline
\end{tabular}

Berdasarkan perhitungan di atas diketahui bahwa persentase keberhasilan kombinasi terapi dingin dan masase dalam menangani cedera ankle sprain akut pada pengukuran gerak inversi adalah sebesar $44.52 \%$.

d. Gerakan Eversi

Tabel 28. Distribusi Data Rerata untuk Gerakan eversi

\begin{tabular}{|c|c|c|}
\hline Pretest & Posttest & Efektivitas \% \\
\hline 7,40 & 11,45 & $54.72 \%$ \\
\hline
\end{tabular}

Berdasarkan perhitungan di atas diketahui bahwa persentase keberhasilan kombinasi terapi dingin dan masase dalam menangani cedera ankle sprain akut pada pengukuran gerak eversi adalah sebesar $54.72 \%$.

Berdasarkan hasil di atas dapat disimpulkan bahwa terapi dingin dan masase dapat meningkatkan ROM sendi ankle pada gerak plantarfleksi sebesar $19.21 \%$, dorsofleksi sebesar $52.06 \%$, inversi sebesar $44.52 \%$, dan eversi sebesar $54.72 \%$. Pengaruh dingin dapat mengurangi suhu daerah yang sakit, membatasi aliran darah dan mencegah cairan masuk ke jaringan di sekitar luka. Hal ini akan mengurangi nyeri dan pembengkakan. Aplikasi dingin dapat mengurangi sensitivitas akhiran saraf yang berakibat terjadinya 
peningkatan ambang batas rasa nyeri (Novita, 2010: 23). Masase akan mengurangi nyeri dan spasme otot, meningkatkan sirkulasi aliran pembuluh darah balik (vena) dan limfatik untuk membantu mengurangi bengkak, serta mengurangi perlekatan jaringan (adhesion) pada daerah cedera (Anderson, 2009: 186). Berkurangnya nyeri dan pembengkakan akan meningkatkan ROM sendi ankle dalam melakukan gerakan meliputi gerak plantarfleksi, dorsofleksi, inversi, dan eversi.

\section{PEMBAHASAN}

Cedera ankle sprain akut merupakan salah satu jenis cedera yang sering dialami oleh seorang atlet. Anggi Saputra (2008: 32) menyebutkan cedera merupakan rusaknya jaringan lunak atau keras yang disebabkan oleh adanya kesalahan teknis, benturan, dan aktivitas latihan fisik yang melebihi batas latihan beban. Aktivitas atlet pencak silat banyak menggunakan tungkai dan kakinya dalam melakukan aktivitas geraknya. Hal ini membuat atlet pencak silat sangat rentan terkena cedera ankle sprain. Cedera yang terjadi dapat mengganggu atlet tersebut untuk berprestasi.

Menurut Anderson (2009: 168) pengaruh dingin dapat menyebabkan vasokonstriksi pada tingkat selular dan menurunkan metabolisme sel (menurunkan kebutuhan oksigen). Permeabilitas kapiler dan nyeri akan berkurang dan pelepasan mediator inflamasi akan dicegah. Pengaruh dingin akan menghambat transmisi nyeri melalui stimulasi serabut saraf yang berdiameter lebih besar yang berada di spinal cord berperan sebagai counterirritant sehingga akan menghambat persepsi nyeri sampai ke otak. Selain itu, pengaruh dingin pada daerah cedera dapat mengurangi suhu daerah yang sakit, membatasi aliran darah dan mencegah cairan masuk ke jaringan di sekitar luka (Novita, 2010: 23). Pengaruh masase pada cedera yaitu, dapat meningkatkan aktivitas pompa vena dan limfe (getah bening) secara artifisial untuk mempercepat pemulihan melalui percepatan sirkulasi dengan mengangkut kembali cairan tubuh yang berada di luar pembuluh darah (Giriwijoyo, 2012: 274).

Secara fisiologis kombinasi terapi dingin dan masase dapat mengurangi proses peradangan yang terjadi berupa kemerahan, panas, dan bengkak. Selain itu berkurangnya nyeri dan pembengkakan akan menimbulkan peningkatan kemampuan menyangga beban tubuh sehingga meningkatkan kemampuan fungsional sendi ankle dalam melakukan aktivitas sehari-hari meliputi berjalan, jongkok jinjit, dan berdiri satu kaki. Berdasarkan uraian di atas, dapat disarankan agar cedera ankle sprain akut cepat pulih sebaiknya diberikan perlakuan 
kombinasi terapi dingin dan masase secara intensif. Hal ini dikarenakan dengan memberikan kombinasi dua perlakuan yang berbeda ini lebih efektif dan signifikan mengurangi kemerahan, suhu panas, lingkar ankle, rasa nyeri, dan meningkatkan ROM pada cedera ankle sprain akut.

\section{KESIMPULAN}

Secara keseluruhan dapat disimpulkan bahwa perlakuan kombinasi terapi dingin dan masase efektif menangani cedera ankle sprain akut pada atlet pencak silat DIY dengan indikasi berkurangnya tanda radang (merah, panas, bengkak, dan nyeri), serta meningkatnya fungsi gerak sendi ankle untuk aktivitas sehari-hari (jalan, duduk, jongkok, dan berdiri satu kaki) dengan signifikan. Pengaruh dingin akan menyebabkan vasokonstriksi pada tingkat selular dan menurunkan metabolisme sel (menurunkan kebutuhan oksigen).

Permeabilitas kapiler dan nyeri akan berkurang dan pelepasan mediator inflamasi akan dicegah. Pengaruh dingin akan menghambat transmisi nyeri melalui stimulasi serabut saraf yang berdiameter lebih besar yang berada di spinal cord yang berperan sebagai counterirritant sehingga akan menghambat persepsi nyeri sampai ke otak (Anderson, 2009: 166). Masase akan meningkatan aliran darah sehingga menyingkirkan produk-produk inflamasi seperti bradikinin, histamin, dan prostaglandin yang menimbulkan nyeri lokal. Selain itu masase juga merangasang trigger point untuk menutup gerbang nyeri sehingga transmisi impuls nyeri ke medulla spinalis dan otak dapat dihambat (Price \& Wilson, 2006: 188). Berkurangnya nyeri akan menimbulkan peningkatan kemampuan menyangga beban tubuh sehingga meningkatkan kemampuan fungsional sendi ankle dalam melakukan aktivitas sehari-hari meliputi berjalan, jongkok jinjit, dan berdiri satu kaki.

\section{DAFTAR PUSTAKA}

Ali Satia Graha. (2009). Pedoman dan Modul Masase Frirage Penatalaksanaan Masase dan Cedera Olahraga pada Lutut dan Engkel. Yogyakarta: Klinik Terapi Fisik UNY.Hardianto Wibowo. (1994/1995). Pencegahan dan Penatalaksanaan Cedera Olahraga. Jakarta: Buku Kedokteran.

Ali Satya Graha dan Bambang Priyonoadi. (2009). Terapi Massage Frirage (Penatalaksanaan Cedera Pada Anggota Tubuh Bagian Atas). Yogyakarta: Fakultas Ilmu Keolahragaan Universitas Negeri Yogyakarta.

Andun Sudijandoko. (2000). Pencegahan Perawatan Cedera. Jakarta: Departemen Pendidikan Nasional.

Bambang Priyonoadi. (2006). Pencegahan dan Perawatan Cedera. Makalah dalam proses pembelajaran PPC untuk mahasiswa FIK. Yogyakarta: FIK UNY. 
Bambang Wijanarko, dkk. (2010). Masase Terapi Cedera Olahraga. Surakarta: Yuma Pustaka.

Best, T. M., R. Hunter, A. Wilcox and F. Haq (2008). Effectiveness of sports massage for recovery of skeletal muscle from strenuous exercise. Clinical Journal of Sport Medicine.

Calatayud J, Borreani S, Colado J. C, Flandes J., (2014). Exercise and Ankle Sprain Injuries A Comprehensive Review. Hal 88-93, vol 42. ISNN: 0091-3847.

Chan K, Ding B, dan Mroczek K, 2011. Acute and chronic lateral ankle instability in the athlete. Bulletin of the Nyu Hospital for Joint Diseases 2011;69(1):17-26 17 .

Cheung K, Hume P, Maxwell. (2003). Delayed Onset Muscle Soreness: Treatment Strategies and Performance Factors. School of Community Health and Sports Studies, Auckland University of Technology, Auckland New Zealand.

Eva Nulis, Erika, Bayakki. (2012). Pengaruh Terapi dingin terhadap Perubahan Intensitas Nyeri Pada Penderita Low Back Pain. Jurnal Ners Indonesia. Vol. 2 hal: 185-191.

Garrison, Susan J. (2001). Dasar-dasar Terapi dan Rehabilitasi Fisik. Jakarta: Hipokrates.

Gerard A.M., Ning Yan., and Jill Stark. (2015). Mekanisms and Efficacy of Heat and Cold Therapies for Musculoskeletal Injuri. New Jersy: Postgraduate Medicine. ISSN: 0035481.

Giriwijoyo, Santosa dan Dikdik Zakar Sidik. 2012. Ilmu Faal Olahraga. Bandung: PT. Remaja Rosdakarya.

Novita Intan Arovah. (2009) .Diagnosis dan Manajemen Cedera Olahraga. FIK UNY.

Rakasiwi A.M. (2013). Aplikasi Terapi dinginSesudah Pelatihan Lebih Baik dalam Mengurangi Terjadinya Delayed Onset Muscle Soreness daripada Tanpa Terapi dinginpada Otot Hamstring. Tesis. Program Pascasarjana Universitas Udayana. Denpasar.

Taylor, Paul M. dan Taylor, Diane K. (ed). (2002). Mencegah dan Mengatasi Cedera Olahraga. Jakarta: PT. Graha Persindo Persada.

Tjipto Soeroso. (1983). Ilmu Lulut Olahraga. Yogyakarta: IKIP.

Wara Kushartanti. (2007). Patofisiologi Cedera Olahraga. Makalah. Yogyakarta: Klinik Terapi Fisik FIK UNY.

Wenniarti, dkk. (2016). Pengaruh Terapi Ice Pack terhadap Perubaha Skala Nyeri Pada Ibu Post Episiotomi. Jurnal Kedokteran dan Kesehatan. Vol. 3 hal: 377-382. 